\title{
Mechanizm rewitalizacji miejskiej zabudowy mieszkaniowo-osadniczej - spostrzeżenia
}

\section{Streszczenie}

Celem opracowania jest wskazanie strukturalnych mechanizmów rewitalizacji w miejskiej zabudowie mieszkaniowej i osadniczej. Dotyczy ono rozwiniętych gospodarek rynkowych w okresie powojennym, a także Polski po 1989 r. W analizie zastosowano podejście retrospektywne (retrospective approach).

W opracowaniu przedstawione są mankamenty rewitalizacji sprowadzone do wymiaru strukturalnych mechanicznych zależności. Służy to zasugerowaniu głębszych źródeł - wystarczająco niejednoznacznych - rezultatów w tej dziedzinie wynikających z praktykowania paradygmatu rynkowego wzrostu ekonomicznego.

Zasygnalizowano także konieczność sięgającego wymiaru cywilizacyjnego przeciwdziałania temu. Zaproponowano pójście w kierunku urzeczywistniania paradygmatu trwałego rozwoju, który uznano za nieodzowny warunek uzyskania satysfakcjonujących osiągnięć w dziedzinie rewitalizacji fragmentów przestrzeni zamieszkanej jako istotnego czynnika równoważenia jej rozwoju.

Na tym tle znaczne możliwości prowadzenia efektywnych działań rewitalizacyjnych - dających szanse wybiegania poza mechaniczny rytm falowań rynku - istnieją w starszych wiekiem osiedlach mieszkaniowych, zwłaszcza tych mających odziedziczoną solidną funkcjonalno-przestrzenną kompozycję.

Słowa kluczowe: rewitalizacja, zabudowa mieszkaniowa i osadnicza, rynkowy wzrost ekonomiczny, trwały rozwój, przestrzeń zamieszkana

DOI: $10.33119 / K S z P P .2019 .3 .3$

1 Instytut Gospodarstwa Społecznego i Kolegium Ekonomiczno-Społeczne Szkoły Głównej Handlowej w Warszawie 


\title{
The mechanism of revitalization of urban housing and settlement development: insights
}

\begin{abstract}
The aim of the study is to indicate structural mechanisms of revitalization of urban residential and settlement housing in post-war developed market economies and in Poland after 1989. In an attempt to achieve this goal, a retrospective approach was applied. A rather one-sided sharpening of the shortcomings of the revitalization presented in the paper by submitting them to structural mechanical dependencies served to suggest deeper sources of sufficiently ambiguous results in this field related to the paradigm of market economic growth. In this way, the necessity was indicated to counteract this approach towards the realization of the paradigm of sustainable development as an indispensable condition for satisfying achievements in the field of revitalization of fragments of space inhabited as an important factor of balancing the development of the inhabited space. Against this background, significant opportunities exist for revitalizing activities, giving the chances of running beyond the mechanical rhythm of market waves, in older housing estates with inherited solid functional and spatial composition.
\end{abstract}

Keywords: revitalization, residential and settlement buildings, market economic growth, sustainable development, inhabited space

Celem opracowania jest wskazanie na strukturalne mechanizmy rewitalizacji miejskiej zabudowy mieszkaniowo-osadniczej w - traktowanych zbiorczo - powojennych rozwiniętych gospodarkach rynkowych oraz w mającej do nich dołączać po 1989 r. Polsce. W próbie osiągnięcia tego celu zastosowano podejście retrospektywne (retrospective approach). Jego istotą jest - w opozycji do podejścia retrogresywnego (retrogressive approach) - metoda zrozumienia teraźniejszości za pomocą podporządkowanej metodzie redukcji - analizy przeszłości (Gregory et al., 2009: 654, 626-627).

Rewitalizacja - zgodnie z łacińskim źródłosłowem - rozumiana jest w opracowaniu jako zespół działań podejmowanych w celu wydobycia danego wyodrębnionego terenu (rzadziej większego obszaru) z zastoju lub upadku społeczno-gospodarczego (Kumaniecki, 1982: 420, 540). Tak rozumie się rewitalizację w państwach o rozwiniętych gospodarkach rynkowych od przełomu lat 70. i 80. XX wieku. Rewitalizacja dotyczy przedsięwzięć mających najbardziej widoczny wymiar architektoniczno-urbanistyczny, a także przedsięwzięć o wymiarze ekologicznym, ekonomicznym, społecznym i technicznym, przy czym waga tych wymiarów może być każdorazowo inna.

Rewitalizacja ma w literaturze przedmiotu co najmniej kilkanaście definicji, przy czym ta przyjęta w Polsce - przez władze jako oficjalna - jest dość ogólna (Ustawa... 
2015 r. Dz.U.). Może ona przybierać różną postać: modernizacji podejmowanej w znacznej skali, gentryfikacji, odnowy, regeneracji, rehabilitacji oraz restrukturyzacji. W rezultacie może wywoływać różny stopień i zakres ogólnego ożywienia oraz poprawy jakości życia lokalnych społeczności. Może zachodzić to w wyniku synergii cech zagospodarowanej przestrzeni urbanizacyjnej i przejawów spójności społecznej.

Rewitalizacja miejsc w przestrzeni zurbanizowanej może być wielopłaszczyznowa, nawiązywać do koncepcji trwałego rozwoju, być oparta na działaniach w zakresie zagospodarowania przestrzennego. Dotyczy zwykle miejsce będących w zastoju społeczno-gospodarczym lub upadających. Celem nadrzędnym jest zawsze spójność społeczna. Gwarantowane formalnie przez liberalizm i neoliberalizm równouprawnienie oraz ogólny wzrost zamożności społeczeństw w rozwiniętych gospodarkach rynkowych, a także w Polsce po 1989 r., nie przekładają się jednak na równość szans związanych z zamieszkiwaniem (Boryczka, 2019: 35) będącą istotnym czynnikiem owej spójności.

Przedsięwzięcia rewitalizacyjne - wpływające na znaczne zmiany w zagospodarowaniu przestrzennym - mają zatem na celu poprawę miejscowego środowiska mieszkalnego, które obejmuje zagospodarowany dla celów mieszkalnych teren, a także usługowe urządzenia towarzyszące, jak również elementy środowiska naturalnego przetworzone przez człowieka na obszarze zamieszkiwania i oddziałujące na niego (Andrzejewski, 1987: 17-19).

W literaturze przedmiotu nie jest przesądzone, czy rewitalizacja koncentrować się ma na cechach fizycznych problemowego obszaru lub miejsca, czy na wspieraniu jego mieszkańców. Pozostaje kwestia względnej równowagi między „fizycznym” i „społecznym” podejściem do rewitalizacji w powiązaniu z ogólnomiejską strategią przeciwdziałania segregacji w miejscu zamieszkania. W praktyce różne są przy tym relacje partnerstwa publiczno-prywatnego, stosunki podmiotów centralnych z lokalnymi, udział mieszkańców w ożywianiu miejskich obszarów problemowych oraz inne (Koczanowicz-Chondzyńska, 2009: 4-15; Przywojska, 2016: 81-126).

Do przeszłości ukształtowanej w drugiej połowie XX w. należy jednak przekonanie, że rewitalizacja może być narzędziem przezwyciężenia segregacji miejskiej w miejscach lub obszarach problemowych. Dziś - zakładając kontynuację paradygmatu wzrostu ekonomicznego opartego na mechanizmach rynku - można pytać tylko, jak ograniczyć narastanie segregacji w skali miast i sąsiedztw. Przemawiają za tym choćby znaczne trudności w promowaniu zróżnicowanej struktury społecznej na upadłych obszarach. Rewitalizacji nie towarzyszy bowiem odpowiednio duża skala taniego budownictwa społecznego o współczesnym standardzie. Problem ten nie znajduje zadowalającego rozwiązania od lat 60 . XX wieku. Natomiast znaczne możliwości skutecznych działań rewitalizacyjnych istnieją - jak zobaczymy - w starszych wiekiem 
osiedlach mieszkaniowych, które nawiązują kompozycją funkcjonalno-przestrzenną do zasad modernizmu. Tam rewitalizacja prowadzona może być $\mathrm{w}$ duchu trwałego rozwoju (Cesarski, 2016: 246-256), co, zdawałoby się, przezwycięża wstępujący lub zstępujący rytm mechanizmów rynku.

Zasygnalizowane generalia, w tym zwłaszcza stosunkowo najbardziej widoczne dodatnie efekty rewitalizacji, są zarazem w największym stopniu dostrzegalne w literaturze przedmiotu. Mniej eksponowane mankamenty działalności rewitalizacyjnej (Anioł, 2017: 10-34; Anioł, 2019: 168-171, 216-220)² będące w przedkładanym opracowaniu głównym przedmiotem rozważań i jednostronnie wyostrzone wynikają z praktyki paru ostatnich dekad XX wieku.

Na tym tle wyjaśnień metodyczno-semantycznych wymaga tytuł opracowania: Mechanizm rewitalizacji miejskiej zabudowy mieszkaniowo-osadniczej-spostrzeżenia. „Spostrzeżenia” to w odczuciu autora główne impresje o strukturalnych cechach i mechanizmach rewitalizacji, niepoparte w opracowaniu rozbudowanym dowodem, co w dwójnasób skłaniać może do dyskusji.

Sformułowanie „mechanizm rewitalizacji” oddaje przyczynowe zależności oddziaływania między materialnymi elementami, oparte na prawach mechaniki podporządkowanej sekwencjom bodźca i reakcji. Były one przedstawiane i analizowane jeszcze w XVIII w. wraz z początkami rewolucji przemysłowej, co w skrajny sposób zostało wyrażone w filozofii mechanistycznej (Osler, 2004: 171-237). Oddziaływania tego typu są coraz bardziej zauważalne po wojnie w państwach liberalnej, a następnie neoliberalnej gospodarki rynkowej. Dochodzi w ich wyniku do długookresowo słabnącego wzrostu ekonomicznego, który podlega w rosnącym stopniu mechanizmom rynku poprzez prawo podaży i popytu.

Wskazana w tytule opracowania „miejska zabudowa mieszkaniowo-osadnicza” służy bezpośrednio zamieszkaniu na powierzchni miejskich obszarów, w tym poddanych rewitalizacji. Ma ona u podłoża podziemną infrastrukturę techniczną wymagającą równoczesnych zabiegów remontowo-modernizacyjnych w ścisłym sensie.

Miejska zabudowa mieszkaniowo-osadnicza, składająca się głównie z mieszkań i budynków mieszkalnych oraz innych naziemnych elementów infrastruktury osadniczej, stanowi trzon przestrzeni zamieszkanej (Cesarski, 2012: 125-149). Sposób kształtowania tej przestrzeni, w którym rewitalizacja może odgrywać rolę pozytywną w zmierzaniu do - nadrzędnej dla trwałego rozwoju - megaspójności społecznej, wpływa decydująco na oblicze pozostałej przestrzeni zamieszkiwania, gdzie człowiek na ogół tylko bywa z większą lub mniejszą częstotliwością.

2 Konkretne celne przykłady mankamentów rewitalizacji oraz ich wyważone z polskiej perspektywy uogólnienia znaleźć można ostatnio w publikacjach W. Anioła. 


\section{Mechanizmy rewitalizacji zabudowy mieszkaniowo- -osadniczej w XX wieku}

W pierwszych powojennych dekadach czołowe państwa zachodnioeuropejskie rozwijały inwestycje mieszkaniowe przeznaczane dla szerszych rzesz społeczeństwa, które finansowały - wprost i pośrednio - z budżetu centralnego. Była to jedna z keynesowskich metod pobudzania popytu, a w konsekwencji wzrostu ekonomicznego. Inwestowanie w społeczne budownictwo mieszkaniowe okazywało się bowiem nieopłacalne w krótkim okresie dla kapitału prywatnego.

Powojenna prosperity lat 50. i 60. umożliwiała znaczne wydatki publiczne, które łagodziły wady mechanizmów rynkowych. Wydatki te pokrywały między innymi koszty masowych wyburzeń zabudowy mieszkaniowo-osiedleńczej pochodzącej z XIX i początków XX wieku. Wyburzenia dyktowane były oddziaływaniem mechanizmu renty gruntowej oraz presją wysokich dotowanych przez sektor publiczny kosztów modernizacji i eksploatacji starego zużytego zasobu zamieszkanego zwykle przez gorzej sytuowaną ludność.

Wyburzenia stanowiły długookresową stratę w wymiarze społeczno-kulturowym, zatem stratę w gospodarowaniu społecznym, przy dopiero początkującym szerszym myśleniu w kategoriach ekologii i trwałego rozwoju (Bookchin, 1970: 4-63; Devall, Sessios, 1985: 2-7; Rottenberg, 1989: 2-22), nieprzekładającym się na praktykę społeczno-gospodarczą.

Wyburzenia przy doraźnych, w sumie, zyskach stricte ekonomicznych, rodziły zazwyczaj wtórne problemy społeczne (Hartman, 2002: 432-461). Były pierwszą wywołaną przez mechanizmy rynku reakcją dającą szanse - przy kontynuacji szybkiego wzrostu ekonomicznego - przyszłej poprawy zamieszkiwania w wymiarze społecznym. Wyburzenia nie mogą być jednak rozpatrywane jako formuła rewitalizacji. Nie zakładają bowiem działań skierowanych bezpośrednio na ożywienie i poprawę jakości życia zastanych społeczności lokalnych. Społeczności te przesiedlane były bowiem w wyniku wyburzeń wykonywanych bezpośrednio w trybie administracyjnym w inne miejsca. Motyw takich przesiedleń będących skutkiem i w tym sensie elementem rewitalizacji, generowanych jednak tylko pośrednio w zawoalowany sposób przez mechanizmy rynku, powraca pod koniec XX wieku. 


\section{Europa po pierwszym szoku naftowym}

W Europie Zachodniej od połowy lat 70. ujawnia się - wraz z „pierwszym szokiem naftowym” - strukturalny kryzys gospodarczy. Zachodzą mechanicznie powiązane w gospodarce rynkowej: spadek dynamiki PKB, wzrost stagflacji, stóp procentowych, nierówności dochodów itp. Przyczyniają się one do powiększania się społecznych nierówności w warunkach zamieszkiwania. Rozwój społeczno-ekonomiczny oparty na keynesowskiej teorii kreowania popytu okazuje się niewystarczający w zestawieniu $\mathrm{z}$ mechanicznymi realiami gospodarki rynkowej.

W keynesowskiej gospodarce dochodzi do napięć na rynku mieszkań właścicieli będących użytkownikami i najmu prywatnego. $\mathrm{W}$ zestawieniu $\mathrm{z}$ uprzednio niedrogim wynajmowaniem mieszkań społecznych (śmielej dotowanym ze środków publicznych) spowalnia to tradycyjną odnowę obszarów miejskich polegającą na remontach zabudowy mieszkaniowej lub jej wyburzeniach, które zwiększają czynsze w mieszkaniach odremontowanych oraz powstałych w miejsce wyburzonych.

Dochodzi do kumulacji tendencji kryzysowych, co wywołuje zmianę formuły działania państw. W nowej sytuacji działania państwa kierują się na uaktywnianie wewnętrznych „ukrytych” sił rozwoju, w tym szukania pomocy u władz lokalnych i regionalnych oraz innych organizacji terytorialnych. Zachodzić zaczyna zmiana od poprzedniego skupiania się na rozwiązywaniu problemów w kierunku działań zmierzających do wyzwalania potencjałów. Przykładem takiego modelu działania staje się rewitalizowanie starego wiekiem zasobu mieszkaniowego i innej zabudowy osiedleńczej z XIX i początków XX wieku.

Ogólniejszą nauką z pierwszych prób przeciwdziałania spadkowi wzrostu ekonomicznego lat 70. jest zapomniana wkrótce konstatacja, że mechanizmy rynku i - tak pożądany w gospodarce rynkowej - wzrost ekonomiczny wymagają naczelnych uzgodnień w zakresie modelu rozwoju społecznego, w tym zamieszkiwania (Donnison, Middleton, 1987: 93-151, 235-247; Cesarski, 1987: 122-126; Giecewicz, 2008: 56-58; Cesarski, 2011a: 125-132). Uczestnictwo państwa jako pośredniego podmiotu wspierającego zamieszkiwanie dotyczyło w latach 70. i 80. głównie aspektów materialnych (fizycznych). Równocześnie, lecz bez zbytniego realnego wpływu na powyższe procesy, dyskutowana była od końca lat 80 . koncepcja trwałego rozwoju stanowiąca reminiscencję raportów Klubu Rzymskiego (zapoczątkowanych w latach 70.) i innych organizacji oraz pojawiania się od 1972 r. w pracach ONZ terminu „ekorozwój" (Bruntland, 1987: passim; Kośmicki, 1996: 97-112; Zabłocki, 2002: 46-63.).

Od lat 80. obserwowane jest wyraźniejsze przestawianie się wielu państw Europy Zachodniej na neoliberalną politykę gospodarczą, w tym miejską. W procesach 
rewitalizacyjnych akcent pada na bezpośrednie oddziaływanie mechanizmów rynkowych podporządkowanych mechanicznemu prawu popytu i podaży. Wywołane jest w ten sposób wrażenie obfitości w zaspokajaniu potrzeb mieszkaniowo-osadniczych. Sprzyja temu znaczne uwolnienie spod interwencji publicznej działania renty gruntowej i pochodnych innych rent ekonomicznych, zwiększające możliwości przechwytywania przez sektor prywatny zysku z lokalizacji ziemi i związanych z tym różnic cen nieruchomości przynoszących dochód (Harvey, 2012: passim).

Wspomniane uczestnictwo państwa jako pośredniego podmiotu wspierającego zamieszkiwanie głównie w aspekcie materialnym (fizycznym) przemienia się w latach 90. w przekonanie o rodzimych - tkwiących w układach terytorialnych - wewnętrznych niematerialnych źródłach rozwoju społeczno-gospodarczego związanych między innymi $z$ rewitalizacją.

\section{Suburbanizacja, reurbanizacja, gentryfikacja}

W zakresie koncepcji terytorium w rozwiniętych gospodarkach Europy Zachodniej akcentuje się pierwszoplanowe znaczenie więzi społecznej. Więź ta obejmuje procesy kulturowe, stosunki międzyludzkie, kształtowanie tożsamości, a także relacje zawodowe, organizację produkcji, zdolności innowacyjne itd. Niematerialne wartości miały bowiem redukować ryzyko generowane przez gospodarkę rynkową oraz podnosić konkurencyjność wspólnot terytorialnych (Pietrzyk, 2000:16-61). Wartości te miały zatem oddziaływać na zdolność do lepszego odnalezienia się owych wspólnot w realiach kreowanych przez mechanizmy rynku.

Tego typu próby poszukiwania pozarynkowych niematerialnych wartości miały za podstawę zaufanie oraz tradycje kulturowe, sprzyjające w sposób obiektywny zdolności do współpracy w układach terytorialnych. Okazały się jednak nieskuteczną - co pokazuje retrospekcja - oddolną reakcją na negatywne oddziaływanie mechanizmu rynku, w wymiarze makroekonomicznym powodującego osłabianie się od lat 70 . tempa wzrostu ekonomicznego w wielu rozwiniętych gospodarkach rynkowych.

U schyłku XX w. nieodzowna dla istnienia kapitalizmu nadwyżka ekonomiczna osiągana była nadal m.in. kosztem rynkowej mieszkaniowej marginalizacji słabszych grup ludności pracowniczej. Wynika to z działań i procesów zachodzących w przestrzeni miejskiej, a powiązanych z rewitalizacją licznymi wspólnymi płaszczyznami - głównie z suburbanizacją, reurbanizacją i gentryfikacją.

Społeczne problemy rewitalizacji sprzyjają suburbanizacji, do czego doszło $\mathrm{w}$ formie mechanicznej przestrzennej ekspansji miast opartej na jednorodzinnym budownictwie mieszkaniowym. Ekspansja miast występuje zwykle w atrakcyjnym 
pierwotnie podmiejskim środowisku mieszkalnym. Wytwarza koszty na ogół nierejestrowane w systemie rachunkowości społecznej (System of National Accounts). Są to koszty wzrostu popytu na działki budowlane, koszty indywidualnego transportu samochodowego (drogi), rozrostu miejscowych usług, nadmiernego zużycia energii itp. Okupione jest to zmniejszaniem się przestrzeni ekologicznej, w tym przestrzeni publicznej. Przestrzeń publiczna staje się w procesie rozlewania się urbanizacji najpierw pusta, dając jeszcze szanse przyszłego rewitalizowania, potem dostępna głównie dla bogatych (Harvey, 2012: 35-36, 112), a w konsekwencji rozmywa się z przestrzenią prywatną (Nawratek, 2012: 58-60).

Dochodzi do aspołecznej segregacji mieszkaniowo-przestrzennej. Segregacja taka objawia się m.in. powrotem do centrów dużych miast tzw. elit menedżersko-technokratycznych i innych grup kreatywnej klasy społecznej w ramach procesu reurbanizacji. Klasa kreatywna nie potrzebuje własnych znacznych zasobów kapitału finansowego i środków produkcji, aby realizować swoje interesy, które sprowadzają się do wyszukanej konsumpcji wynikającej z tzw. kapitału kulturowego tej klasy.

Klasa ta przewodzi procesom gentryfikacji upadłych dawnych centrów miast i odnowy innych terenów miejskich w wymiarze społeczno-ekonomicznym oraz kulturowym, w tym symbolicznym. W sumie staje się liczącą się siłą rozwoju miast. Jej kapitał kulturowy jest bowiem wspierany kapitałem finansowym deweloperów.

Gentryfikacja przeprowadzana zazwyczaj środkami sektora prywatnego zachodzi również w coraz większym stopniu poprzez przechwytywanie różnego rodzaju wartości wytworzonych przez zasiedziałą jeszcze lokalną niezamożną społeczność. Społeczność ta po pewnym czasie musi opuścić śródmiejską zabudowę mieszkaniową z uwagi na rynkowe windowanie czynszów przez deweloperów, którzy wykorzystują rentę monopolową poprzez oferowanie drogich mieszkań zamożnym nabywcom zyskującym możliwość zamieszkiwania na terenie o unikalnym kapitale symbolicznym. Tym samym w wyniku wstępujących mechanizmów mnożnikowych zamieszkiwanie w danej przestrzeni lokalnej staje się możliwe głównie dla majętnej ludności (Harvey, 2012: 37-40, 43, 119,154-160; Nawratek, 2012: 118-121). Rynek, w tym rynek mieszkaniowy, wycenia bowiem wysoko względnie rzadkie dobra - w tym przypadku kapitał symboliczny.

Przezwyciężanie miejskiej segregacji mieszkaniowo-przestrzennej - poprzez bardziej z natury wieloaspektową niż gentryfikacja rewitalizację - napotyka bariery. Powstają one zwłaszcza, gdy rewitalizacja przybiera formę prób regeneracji, czyli radykalnej transformacji przestrzeni i zamieszkujących ją $\mathrm{w}$,idealny neoliberalny świat” (Nawratek, 2012: 101). Rewitalizacji - i w jeszcze większym stopniu regeneracji - nie towarzyszy bowiem odpowiednio duża skala taniego nowoczesnego budownictwa społecznego, na którą nie pozwala mechanizm wolnego rynku mieszkaniowego. 
Współczesna formuła rewitalizacji nie rozwiązuje na ogół problemów zamieszkiwania człowieka $w$ środowisku materialnym złożonym ze środowiska naturalnego oraz trwałego zainwestowania, w tym związanych $\mathrm{z}$ nim problemów stricte mieszkaniowych. Przesuwa je w mechaniczny sposób głównie z pomocą rozpraszania i wypierania ludności wykluczonej - jak w szczególnym przypadku gentryfikacji i regeneracji - w inne miejsca (Harvey, 2012:38-40), przede wszystkim na peryferie miast. Ludność zasiedziała jest rugowana z miejsc zamieszkania o znanej sobie swojskiej estetyce. W nowych miejscach zamieszkania pozbawiana jest społecznej więzi i solidarności. Pod pozytywnym hasłem rewitalizacji mechanizmy rynku w sposób ukryty wywołały przesiedlenia na przełomie XX i XXI w. (Cesarski, 2015:261-277).

Rynek wymaga zwrotu kosztów rewitalizacji, co możliwe jest poprzez osiedlanie się dobrze sytuowanej ludności. Rewitalizacji podlega zatem przestrzeń fizyczna, a przestrzeń społeczna wytwarzana jest na ogół od nowa. Kapitał prywatny zaczyna eksploatować zrewitalizowaną genetycznie wspólną przestrzeń miejską (Osiński, 2014: 26-35). Taki przebieg dezurbanizacji i reurbanizacji wpływa na „odwracanie się" infrastruktury osadniczej od przestrzeni publicznej w kierunku rozwoju technicznie pojmowanej infrastruktury bezpieczeństwa ludzi bogatych.

Wiąże się to ze zmieniającą się przestrzenią fizyczną podporządkowywaną wytwarzaniu i reprodukcji relacji społecznych opartych na rywalizacji ekonomicznej. Wzmacniane $\mathrm{w}$ ten sposób w realiach rynkowego paradygmatu wzrostu ekonomicznego procesy suburbanizacji, a następnie niekontrolowanej dezurbanizacji, osłabiają formalnie sprzyjającą trwałemu rozwojowi politykę reurbanizacyjną, $\mathrm{w}$ tym rewitalizacyjną.

\section{Rewitalizacja osiedli mieszkaniowych - mechanizmy a polskie doświadczenia po $1989 \mathrm{r}$.}

Wobec wskazanej powyżej stosunkowo niewielkiej skuteczności globalnych mechanizmów rewitalizacji w odniesieniu do zabudowy mieszkaniowo-osadniczej powstaje kwestia skuteczności działań rewitalizacyjnych w zakresie osiedli mieszkaniowych. Są to jednostki urbanistyczne o względnie ujednoliconej zabudowie mieszkaniowo-osadniczej, która powstawała od międzywojnia, głównie z myślą o lepszym zamieszkiwaniu ludności pracowniczej, w tym wzmacnianiu jej więzi społecznej.

W większości państw Europy Zachodniej od lat 90. XX w. polityka urbanistyczna i mieszkaniowa jest coraz częściej kierowana na modernizowanie dużych osiedli mieszkaniowych. W najbardziej rozwiniętych gospodarkach przeradza się to w wielopłaszczyznowe akcje rewitalizacji. Dostarczają one przykładów osiągnięć w tym zakresie. 
Akcentuje się potrzebę zintegrowanego rozwiązywania problemów natury fizyczno-technicznej równolegle z kwestiami społecznymi, gospodarczymi oraz dotyczącymi środowiska naturalnego, wraz z pożądanym udziałem mieszkańców. Mieszkańcy tych osiedli stać się mają konsumentami i zarazem klientami oraz partnerami zmasowanych działań modernizacyjnych prowadzonych jednak w rynkowym otoczeniu. Jako dowód na możliwe do osiągnięcia efekty w tym zakresie przytaczane są w publikacjach szczegółowe relacje z przeprowadzonych za granicą modernizacji i rewitalizacjach osiedli mieszkaniowych oraz powiązanych z nimi typów terenów (Chmielewski, Marecka, 2007: 59-197; Guzik, 2009: 95-111; Skalski, 2009: 91-112, 213-233; Bryx, Jadach-Sepioło, 2009: 112-142).

Osiedla mieszkaniowe powstałe w Polsce przed 1989 r. stanowią integralny element obecnych struktur przestrzennych oraz przyszłości polskich miast. Stają się jednak często przedmiotem w wielu wypadkach płytkiej krytyki. Osiedla te wymagają systematycznych badań dotyczących oceny ich wartości użytkowej, estetyki. Wymagają także koncepcji modernizacji i rewitalizacji, które byłyby wolne od wstępnego zakładania, że ich przestrzeń społeczna oparta jest na błędnej ideowo i rzekomo trwale patologicznej podstawie.

Mniejsze osiedla z przełomu lat 50. i 60. zostały zwykle dobrze zaprojektowane pod względem funkcjonalno-przestrzennym. Niekiedy tylko proste działania modernizacyjne mogą wpłynąć tam na pozytywne asocjacyjne i zaangażowane zachowania mieszkańców oraz zapobiegać ich selekcji pod względem ekonomicznym. Korzystną zmianę w społecznościach takich osiedli wywołuje odnowa nawierzchni traktów pieszych, wymiana instalacji technicznych $\mathrm{w}$ budynkach $\mathrm{z}$ nową lub odnowioną elewacją, regeneracja terenów zielonych w osiedlach podporządkowanych układom przestrzeni otwartych, w tym przestrzennej dostępności mieszkańców do atrakcyjnych sąsiednich terenów.

Zmiany polegają tam nie tyle na osiedlaniu się ludzi dobrze sytuowanych materialnie, ile na upowszechnianiu się głębszych zainteresowań, sąsiedztwa i lepszego stylu życia. Przykładami w tym zakresie mogą być modernizacje na warszawskim Żoliborzu w prekursorskich międzywojennych koloniach WSM (Gawryszewska, 2011: 241) oraz powojennych osiedlach WSM: „Sady Żoliborskie” (Skibniewska, 1974: 185-228) i „Zatrasie” (Nowicki, 1964: 1-2).

W Polsce istnieje też zabudowa osiedlowa o dużej skali, która pochodzi głównie z lat 70. i 80. i jest na ogół w różnym wymiarze zdegradowana. Stanowi ona istotny ze względów społeczno-gospodarczych element majątku trwałego i narodowego (Chmielewski, Marecka, 2007: 54-58). Walory użytkowe tego majątku oddziaływać będą przez dekady na standardy osiedleńcze znacznej części społeczeństwa polskiego. Wielorodzinna osiedlowa zabudowa mieszkaniowa decyduje o strukturze miasta. 
Szuka się zatem głębszych uzasadnień dużych osiedli mieszkaniowych opartych na zmienionych zasadach kompozycji architektoniczno-urbanistycznej i programu użytkowego, a także na opiniach ich mieszkańców (Wojtkun, 2004: 19-205).

W osiedlach takich nie występuje w znaczącej skali proces filtracji mieszkańców, a ich układ przestrzenny - trudniejszy do przekształcenia - ma stosunkowo mniejsze znaczenie w ocenie wartości użytkowej zamieszkiwania niż położenie, w stosunku do śródmieścia stosunkowo łatwo kształtowalne dostępnością przestrzenną (czas i koszt przemieszczania się). Wśród mieszkańców osiedli mających ponad 20 lat zwykle istnieją trwałe więzy społeczne przekładające się na emocjonalny stosunek do przestrzeni zamieszkania. Są to dodatkowe argumenty za zasadnością akcji modernizacji i rewitalizacji dużych osiedli mieszkaniowych.

Konieczne jest wprowadzanie zmian do struktur takich osiedli: przede wszystkim uzyskanie większej powierzchni użytkowej mieszkań poprzez modyfikację ich układu funkcjonalno-przestrzennego, poprawa stanu infrastruktury technicznej wewnątrz i na zewnątrz zabudowy mieszkaniowej. Pożądane byłoby wzbogacanie programu infrastruktury społecznej oraz lepsze zagospodarowanie terenów otwartych, zwłaszcza w osiedlach z wielkiej płyty (Wojtkun, 2004: 19-205). Osiedla mieszkaniowe z lat 70. i 80. zrealizowane w technologii prefabrykowanej charakteryzują się bowiem specyficznymi problemami wywołującymi konieczność skoncentrowania kreacji i modernizacji osiedlowej przestrzeni mieszkalnej na „funkcjonalno-estetyczno-społecznej” płaszczyźnie (Gronostajska, 2007: 87-328).

Nawet jeśli osiedla pochodzą z odległych okresów - różniących się jak w Polsce uwarunkowaniami ustroju polityczno-państwowego i sposobem zaspokajania potrzeb mieszkaniowych - akceptacja ich cech funkcjonalno-przestrzennych przez mieszkańców jest w znacznym stopniu niezależna od upływu czasu, a działania modernizacyjno-rewitalizacyjne wydatnie dopomagają temu procesowi (Wojtkun, 2008: 6-77, 135-156).

Wartością zmodernizowanych osiedli mieszkaniowych pozostaje na ogół ich dobra lokalizacja w przestrzeni miasta, stanowiąca stabilny czynnik sprzyjający trwałemu rozwojowi. Działania modernizacjno-rewitalizacyjne mają również przewagę nad nowym budownictwem polegającą na ograniczaniu zużycia ziemi i całej przestrzeni ekologicznej, czyli dóbr nieodtwarzalnych. Pozytywny mechanizm może się przejawiać w próbach łączenia modernizacji i rewitalizacji osiedli mieszkaniowych sprzed $1989 \mathrm{r}$. z promowaniem koniunktury terytorialnej w formie ułatwień lokalowo-infrastrukturalnych dla małej i średniej przedsiębiorczości, której potencjalnie blisko do wpisywania się w trwały rozwój w aspekcie ekonomicznym. Kwestią otwartą pozostaje stopień uzależnienia rewitalizacji osiedli mieszkaniowych od mechanizmów i przebiegu koniunktury terytorialnej czy też 
innych, niewychodzących poza rynkowe realia, czynników, np. umiejętności i starań w pozyskiwaniu środków unijnych. $Z$ drugiej strony, rewitalizacja osiedli stanowi czynnik sprzyjający koniunkturze terytorialnej poprzez wzrost potencjału społeczno-gospodarczego nie tylko terenów osiedlowych i zamieszkujących je społeczności, lecz znacznie większych obszarów i grup społecznych (Cesarski, 2011: 169-196), włączając w to pozyskiwanie środków z UE.

\section{Wyzwania rewitalizacji zabudowy mieszkaniowo- -osadniczej w XXI w. - zakończenie i wnioski}

W opracowaniu przedstawiono - w sposób wyostrzony - mankamenty rewitalizacji miejskiej zabudowy mieszkaniowo-osadniczej w powojennych rozwiniętych gospodarkach rynkowych oraz w Polsce po 1989 r. Metodą analizy było podejście retrospektywne umożliwiające sprowadzenie tych mankamentów do strukturalnych mechanicznych rynkowych zależności. W konsekwencji zasugerowano, że istnieją głębsze źródła wystarczająco niejednoznacznych rezultatów w tej dziedzinie związanych z obowiązującym dziś paradygmatem rynkowego wzrostu ekonomicznego.

Zaproponowano więc konieczność oparcia się w działaniach publicznych na paradygmacie trwałego rozwoju. Jest on nieodzowny, aby polityka przestrzenna przynosiła satysfakcjonujące osiągnięcia $\mathrm{w}$ dziedzienie rewitalizacji fragmentów przestrzeni zamieszkanej.

Miejska zabudowa mieszkaniowo-osadnicza stanowi trzon przestrzeni zamieszkanej. Rewitalizacja może odgrywać pozytywną rolę w równoważeniu rozwoju tej przestrzeni w aspekcie megaspójności społecznej, w tym sprawiedliwości wewnątrz i międzypokoleniowej, którym de facto służyć ma urzeczywistnianie trwałego rozwoju.

Można zatem postawić - wymagającą dalszych badań - tezę, że rewitalizacja miejskiej zabudowy mieszkaniowo-osadniczej powinna zostać oparta na koncepcji infrastruktury osadniczej. Koncepcja ta umożliwia, zgodnie z kluczowym dla niej kryterium funkcjonalno-przestrzennym, ciąg spójnego myślenia i działania prowadzący od owego osiągalnego już niekiedy dziś funkcjonalnego mieszkania ku nieosiągalnej w pełni w dającej się przewidywać perspektywie zrównoważonej przestrzeni zamieszkiwania. Spina, również w aspekcie prawidłowego przebiegu procesów rewitalizacji, tak potrzebne równoważenie rozwoju przestrzeni zamieszkanej i pozostałej przestrzeni zamieszkiwania z promieszkaniową i proosadniczą realizacją trwałego rozwoju (Cesarski, 2012: 125-149).

Sprawdza się to już w dobrze pierwotnie zaprojektowanych - pod względem kompozycji funkcjonalno-przestrzennej - osiedlach mieszkaniowych. Przykładem 
są osiedla budowane od międzywojnia także w Polsce wraz z kształtowaniem się polskiej szkoły podchodzenia do zagadnień mieszkaniowych (Cesarski, 2013: 47-118). Ma to miejsce mimo narastających powojennych deformacji idei osiedla społecznego (Syrkus, 1976: passim) związanych z większymi niż w zachodniej gospodarce rynkowej obiektywnymi - wynikającymi z małego potencjału gospodarczego i w zasadzie z braku oddziaływania mechanizmów rynku - ograniczeniami w forsowaniu wzrostu ekonomicznego i potęgowanej założeniami ustrojowymi presji ilościowych potrzeb mieszkaniowych.

Utrudnienia i bariery w tym zakresie - słabo często uświadamiane - leżą w sferze mentalnej, w nadal łatwym odrzucaniu w Polsce dziedzictwa modernizmu, w dewaluowaniu wielu twórczych postulatów takiego myślenia (Supińska, Szewczyk, 2009: 91-94).

Uogólniając, osiedla mające solidne funkcjonalno-przestrzenne podstawy są reaktywnie plastycznym obszarem wieloaspektowych działań rewitalizacyjnych, mniej niż inne zależnym od mechanicznych falowań rynku. Modernizowanie i rewitalizowanie osiedli mieszkaniowych zachowywać powinno harmonijne i funkcjonalne osiedla ludzkie stanowiące podstawowy wyznacznik ładu przestrzeni zamieszkanej, decydującego o trwałym rozwoju.

Rewitalizacja osiedli pochodzących z lat 70. i 80. zmierza słusznie między innymi w kierunku poszukiwania tam wartości zbieżnych z koncepcją (i rzeczywistymi cechami) jednostki sąsiedzkiej wywodzącej się z lat 20. XX w. (Perry, 1939: 50-141; Nowicki 1965: passim; Wallis, 1974: passim; Wojtkun, 2014: 60-79). Niedoceniane jest tu jednak - nie tylko w Polsce - prekursorskie znaczenie myślenia i międzywojennej realizacji osiedli WSM oraz ich powojennych pochodnych (Gawryszewska, 2011: 241; Skibniewska, 1974: 185-228; Nowicki, 1964: 1-2.). Są to bowiem kompozycje zorientowane bardziej prospołecznie i równościowo niż przestrzenno-socjologizująca, raczej tylko porządkująca zastaną rzeczywistość, koncepcja jednostki sąsiedzkiej.

Spuścizna pozytywnych funkcjonalno-przestrzennych rozwiązań w kształtowaniu zabudowy mieszkaniowej opiera się zatem stosunkowo najlepiej stwierdzonym negatywnym mechanizmom rewitalizacji. Nie zmieniają tego odziedziczone rzekomo niższe, w zestawieniu z wykreowanymi przez współczesne mechanizmy rynku, generalne standardy mieszkaniowo-osiedleńcze. Stan taki się utrzymuje mimo odejścia w Polsce po 1989 r. od wyolbrzymianych - jak zasadnie się wskazuje - negatywów „rewolucji mieszkaniowej", która dokonała się w tzw. realnym socjalizmie oraz w kapitalizmie zaraz po wojnie, na rzecz rozwoju własnościowego budownictwa indywidualnego (Łukasiewicz, 2017: 231-233). 
Rewitalizacja ma podtrzymywać i rozwijać również zachodnie przedwojenne założenia i działania w zakresie modelu mieszkalnictwa i osadnictwa. Modelu opartego na niewielkich powierzchniowo mieszkaniach zgrupowanych w osiedla wraz z otoczeniem urbanistyczno-budowlanym, których architektura jest rozpoznawalna $\mathrm{i}$ „niepozbawiona spokojnej nowoczesności wynikającej z funkcji”. Zarazem jest ona różnorodna detalem i wykończeniami związanymi także z pomocniczymi pomieszczeniami w budynku, mającymi zmniejszać niedostatki umiarkowanej powierzchni mieszkań (Giecewicz, 2008: 56-58; Cesarski, 2011a: 125-132).

Te cechy bliskie są przedwojennemu modernizmowi, zwłaszcza zasadom Bauhausu, a przede wszystkim jednak myśli polskiej szkoły podchodzenia do zagadnień mieszkaniowych. Przykładem jest żoliborska WSM, która wytyczyła kierunek budownictwa społecznego opartego na purystycznej i oszczędnej architekturze funkcjonalnej, jak u Corbusiera zachwycającego się klarownością przestrzeni klasztorów (Giedion, 1968: 511-602; Frampton, 2001: 20-149: Friedewald, 2009: 4-128). Jest to kierunek wychodzący jednak poza budynek mieszkalny oraz racje ściśle architektoniczne i ekonomiczne, który integruje obiekty i urządzenia z zakresu dzisiejszej infrastruktury osadniczej. Wraz z modernizacją obejmującą większe obszary miejskie i rozwojem infrastruktury osadniczej wzrasta dostępność przestrzenna dużych osiedli mieszkaniowych. Szerzej pojmowana infrastruktura osadnicza wykracza więc poza teren osiedli w swoim prorozwojowym oddziaływaniu.

Okoliczności te przemawiają za akcjami rewitalizacji dużych osiedli mieszkaniowych pod względem nie tylko ich funkcji asocjacyjnych, lecz także gospodarczych poprzez tworzenie warunków lokalowych i infrastrukturalnych dla przedsiębiorczości małej i średniej, sprzyjającej trwałemu rozwojowi. Takie działania, obejmujące duże osiedla mieszkaniowe, przeradzają się w obiecującą, wielopłaszczyznową rewitalizację nowego typu. Nie ma w niej przemieszczeń osiedleńczych, przesadzania np. z nadmierną rozbudową infrastruktury zmotoryzowanej komunikacji indywidualnej. Takie rewitalizowanie osiedli mieszkaniowych stanowi czynnik wzrostu potencjału społeczno-gospodarczego większych obszarów i grup społecznych.

\section{Bibliografia}

Andrzejewski, A. (1987). Polityka mieszkaniowa. Warszawa: PWE.

Anioł, W. (2017). Między starym a nowym. O sposobach modernizacji przestrzeni publicznych.

Studia z Polityki Publicznej, 2(14): 10-34.

Anioł, W. (2019). Bezład warszawski. O erozji i odnowie przestrzeni publicznych. Poznań: Elipsa. Bookchin, M. (1970). Ecology and revolutionary thought. New York: Times Change Press: 4-63. 
Boryczka, E.M. (2019). Rewitalizacja jako narzędzie sprawiedliwości społecznej, w: Ekonomiczny kontekst sprawiedliwości społecznej i środowiskowej. Ksiega abstraktów, M. Feltynowski, A. Rzeńca, P. Legutko-Kobus, E. Jastrzębska (red.). Łódź: Wydawnictwo Uniwersytetu Łódzkiego: 35.

Bruntland, G. (red). (1978). Our common future. New York: Oxford University Press.

Bryx, M., Jadach-Sepioło, A. (red.) (2009). Rewitalizacja miast w Niemczech, Rewitalizacja Miast Polskich, t. 3. Kraków: IRM.

Cesarski, M. (1989), recenzja książki: Regenerating the inner city. Glasgow's experience, (1987). Donnison, D., Middleton, A. London: Routledge \& Kegan Paul. Sprawy Mieszkaniowe: 122-126.

Cesarski, M. (2011). Modernizacja polskich osiedli mieszkaniowych sprzed 1989 r. - przejawy koniunktury terytorialnej. Studia i Prace Kolegium Ekonomiczno-Społecznego, 3(7): 169-196.

Cesarski, M. (2011a), recenzja książki: J. Giecewicz, Konserwatywna awangarda. Wiedeńska polityka mieszkaniowa 1920-2005. Warszawa: Oficyna Wydawnicza Politechniki Warszawskiej. Człowiek i Środowisko, 1-2: 125-132.

Cesarski, M. (2012). Od funkcjonalnego mieszkania ku zrównoważonej przestrzeni zamieszkiwania - rola infrastruktury osadniczej. Studia i Prace Kolegium Ekonomiczno-Społecznego, 2(10): 125-149.

Cesarski, M. (2013). Polityka mieszkaniowa w Polsce w pracach naukowych 1918-2010. Dokonania i wplyw polskiej szkoły badań. Warszawa: Oficyna Wydawnicza SGH.

Cesarski, M. (2015). Fikcje rynku mieszkaniowego a prawo do miasta, w: Współczesny matrix? Fikcja w życiu gospodarczym, politycznym i społecznym, J. Osiński (red.). Warszawa: Oficyna Wydawnicza SGH: 261-277.

Cesarski, M. (2016). Sytuacja mieszkaniowa w Polsce lat 2002-2014 - światowy kryzys, niewiadome i szanse zamieszkiwania. Warszawa: Oficyna Wydawnicza SGH.

Chmielewski J.M., Marecka, M. (2007). Modernizacja osiedli mieszkaniowych. Warszawa: Oficyna Wydawnicza Politechniki Warszawskiej.

Devall, B., Sessios, G. (1985). Deep ecology: living as if nature mattered. Utah: Gibbs Smith.

Donnison, D., Middleton, A. (1987). Regenerating the inner city. Glasgow's experience. London: Routledge \& Kegan Paul.

Frampton, K. (2001). Le Corbusier (World of Art). London: Thames \& Hudson.

Friedewald, B. (2009). Bauhaus. Munich, New York: Prestel.

Gawryszewska, B.J. (2011). Krajobraz osiedli mieszkaniowych a budowanie więzi sąsiedzkich w programach rewitalizacji. Prace Komisji Krajobrazu Kulturowego, 15: 241.

Giecewicz, J. (2008). Konserwatywna awangarda. Wiedeńska polityka mieszkaniowa 1920-2005. Warszawa: Oficyna Wydawnicza Politechniki Warszawskiej.

Giedion, S. (1968). Przestrzeń, czas, architektura. Narodziny nowej tradycji. Warszawa: PWN.

Gregory, D., Johnston, R., Pratt, G., Michael, J., Watts, M., Whatmore S. (red.) (2009). The dictionary of human geography, 5th edition. Chichester: A John Wiley \& Sons, Ltd.

Gronostajska, B.W. (2007). Kreacja i modernizacja przestrzeni mieszkalnej. Teoria i praktyka na przykładzie realizacji wrocławskich $z$ lat 1970-1990. Wrocław: Oficyna Wydawnicza Politechniki Wrocławskiej. 
Guzik, R. (red.) (2009). Rewitalizacja miast w Wielkiej Brytanii, Rewitalizacja Miast Polskich, t. 1. Kraków: IRM: 95-111.

Hartman, Ch. (2002). The housing of relocated families, w: The city. Critical in social sciences, M. Pacione (red.). London and New York: Routledge: 432-461.

Harvey, D. (2012). Bunt miast. Prawo do miast i miejska rewolucja. Warszawa: Fundacja Bęc Zmiana.

Koczanowicz-Chondzyńska, J. (2009). Rewitalizacja. Biuletyn FISE, 3: 4-15.

Kośmicki, E. (1996). Koncepcja zrównoważonego rozwoju. Nauka, 2: 97-112.

Kumaniecki, K. (opr.) (1982). Słownik łacińsko-polski. Warszawa: PWN: 420, 540.

Łukasiewicz, D. (2017). Dobre i złe adresy. Szkice z dziejów mieszkania i jego otoczenia w XVIIXXI w. Poznań: Wydawnictwo Silva Rerum.

Nawratek, K. (2012). Dziury w całym. Wstęp do miejskich rewolucji. Warszawa: Wydawnictwo Krytyki Politycznej.

Nowicki, J. (1974). Jednostka sasiedzka. Warszawa: WSM.

Nowicki J. (1964). Urządzenia społeczne i usługowe w osiedlu Zatrasie. Życie WSM, 3: 1-2.

Osiński, J. (2014). Sfera publiczna i sfera prywatna - w poszukiwaniu modus vivendi, w: Polityka publiczna we współczesnym państwie, J. Osiński (red.). Warszawa: Oficyna Wydawnicza SGH: 26-35.

Osler, M.J. (2004). Divine will and the mechanical philosophy: Gassendi and Descartes on contingency and necessity in the created world. Cambridge: Cambridge University Press Cambridge.

Perry, C. (1939). Housing for the mechanic age. New York: Russell Sage Foundation.

Pietrzyk, I. (2000). Polityka regionalna Unii Europejskiej i regiony w państwach członkowskich. Warszawa: Wydawnictwo Naukowe PWN.

Przywojska, J. (2016). Rewitalizacja miast. Aspekt społeczny. Łódź: Wydawnictwo Uniwersytetu Łódzkiego.

Rottenberg, D. (1989). Introduction: ecosophyt - from institution to system, w: A. Naess, D. Rothenberg (red.), Ecology, community and lifestyle. London: Cambridge University Press: 2-22.

Skalski, K. (red.) (2009). Rewitalizacja miast we Francji. Rewitalizacja Miast Polskich t. 2. Kraków: IRM.

Skibniewska, H. (1974). Rodzina a mieszkanie. Warszawa: PWN.

Supińska, J., Szewczyk, Ł. (2009). O społecznych konsekwencjach (braku) polityki mieszkaniowej w Polsce, w: Miejsce i rola mieszkalnictwa w okresie kryzysu gospodarczego. Spała: PZIiTB OW, PTM, 6-7 października: 91-94.

Syrkus, H. (1976). Ku idei osiedla społecznego. Warszawa: PWN.

Ustawa z dnia 9 października 2015 r. o rewitalizacji, Dz.U. 2015, poz. 1777.

Wallis, A. (1974). Pojęciowy model jednostki mieszkaniowej. Warszawa: IKŚ.

Wojtkun, G. (2004). Osiedle mieszkaniowe w strukturze miasta XX wieku. Szczecin: Wydawnictwo Uczelniane Politechniki Szczecińskiej. 
Wojtkun, G. (2008). Wielorodzinne budownictwo mieszkaniowe. Wizje a rzeczywistość, Prace Naukowe Politechniki Szczecińskiej 591(46). Szczecin: Wydawnictwo Uczelniane Politechniki Szczecińskiej.

Wojtkun, G. (2014). Nowoczesne mieszkalnictwo w Stanach Zjednoczonych a pryncypia europejskiej awangardy w architekturze. Space \&FORM/Przestrzeń i FORMA, 22(3): 60-79.

Zabłocki, G. (2002). Rozwój zrównoważony. Idee, efekty, kontrowersje. Toruń: Uniwersytet Mikołaja Kopernika. 